\title{
AN UNMANNED AERIAL SURVEILLANCE SYSTEM IN URBAN ENVIRONMENTS
}

\author{
Petar Getsov ${ }^{1,2}$,Wang Bo ${ }^{1}$, Dimo Zafirov², Georgi Sotirov², \\ Stanimir Nachev ${ }^{2}$, Ruslan Yanev ${ }^{2}$, Pavlin Gramatikov ${ }^{2}$, Valentin Atanassov², \\ Hristo Lukarski ${ }^{2}$, Svetoslav Zabunov ${ }^{2}$ \\ ${ }^{1}$ Ningbo University of Technology - China \\ ${ }^{2}$ Space Research and Technology Institute - Bulgarian Academy of Sciences
}

\begin{abstract}
Proposed is a concept for a network of unmanned aerial systems for information acquisition in an urban environment. Different possibilities are evaluated using different types of aircraft, sensors and systems for obtaining the required objective, instrumental real-time information to support the making of adequate and reasoned management decisions, which will greatly contribute to the improvement of the quality of life of the population. The system can be applied for the detection of low flying objects, for monitoring, management and security of urban intersections, underground stations, public and private buildings, and to determine the state of the atmosphere and water areas. It will provide the opportunity to forecast and manage crises that may arise in the context of the critical urban infrastructure.
\end{abstract}

\section{Introduction}

Prognoses have been made that in 2050 up to $66 \%$ (more than 6 billion people) of the earth's population will be living in cities and the number of cities with multi-million population will be constantly increasing. At the same time, the requirements of society for providing high quality of life and reducing of the influence of urban development upon the biosphere are ever increasing. This tendency makes us looking for possibilities to create systems that utilize the latest technical and technological developments which will allow the attainment of these requirements.

This data is being analyzed, structured and archived and is made available to people and organizations involved with the functioning and development of the smart city.

At this moment there is no universally acknowledged definition of a smart city. For the purpose of this work the authors have accepted that smart cities are those utilizing the most advanced knowledge, technology and other means for the constant improvement of the quality of life for its citizens and the environment as a whole. 
For the adequate governing of a smart city a large amount of data is needed (both real time and from archives) provided by a system of sensors. This data is being analyzed, structured and archived and is made available to people and organizations involved with the functioning and development of the smart city. The system of sensors consists of devices mounted on space, aerial, land and water (stationary or mobile) carriers that gather information in real time and transmit it to other systems.

This system can be applied for the management and security provision for critical urban infrastructure, intersections, underground stations, public and private buildings for timely and adequate management of the intelligent city.

Aeronautical systems make it possible to receive and deliver information in real time with very high accuracy. Particularly promising are unmanned aerial vehicles (UAV), with which the cost of the received information is lower than with the use of satellites and manned aircraft. It is expected that by the year 2022 the total volume of the market for UAV systems will reach $\$ 21.3$ billion with an average annual growth rate of $20 \%$. There are estimates that this tendency is to deepen in favour of small UAV weighing up to $150 \mathrm{~kg}$.

Now nearly $98 \%$ of the worlds UAVs are heavier than air, 68 percent are of fixed wing type and rotary wing $-27 \%$. The proportion of the lighter than air aircraft is negligible - less than $1 \%$.

Unmanned aerial vehicles are becoming more efficient and more widely used, both for civil and military purposes and they themselves are starting to threaten the security of the population and air traffic, especially in the context of the urban environment. Taking into account the dangers that they can pose when they are not in the zone of direct visibility in urban areas and are under the altitude covered by conventional systems for air traffic management, there are needed activities, technical means and precautions that need to be taken to avoid unwanted actions and related consequences.

In addition, unlike traditional air targets, they are of small mass $(25 \mathrm{~kg})$, flying at low altitudes $(<150 \mathrm{~m})$ and are moving with velocity $(<90 \mathrm{~km} / \mathrm{h})$, which makes them difficult and almost impossible to detect against the background of the joint urban terrain, characterized with tall buildings, moving people and vehicles, as well as the presence of other sources of electromagnetic, thermal, and other emissions. At the same time, the existing well-developed system for the management and air traffic control cannot be used, since the probability of detecting the unmanned aerial vehicles under specified conditions is very small.

All this leads to the development and use of special systems and sensors for the detection of low flying objects based on the different physical nature of the processes and the phenomena characterizing the functioning of UAV in real time. The concept of the monitoring system for urban environment is based on setting up a network for the surveillance of individual UAV platforms with the required scope and duration of flight, which will cover a city and its adjacent urban areas and was 
designed according to the requirements established by DARPA (Defense Advanced Research Projects Agency) in the document DARPA-BAA-16-55 (Fig. 1) [2]. The Aerial Dragnet concept is based on multilevel communication, analyzing and control technology, using UAVs as tool for defense of the airspace in urban areas when intruding drones compromise the protected area.

In addition, the system carries out the classification and tracking of all small UAVs and provides a continuous updated common operational picture for the airspace under $300 \mathrm{~m}$, which contains the geo refined trajectories of UAVs labeled as friend or foe in the defined area of responsibility. The dissemination of information is related to accredited users depending on the interfaces of existing security requirements of civil or military lines.

Individual system platforms are connected to a network, which allows more extensive and better coverage of the urban territory, depending on the height of the individual units. The cost of the system is relatively low, as it uses already existing and developed platforms, components and software, and the signal processors are conventional. At the same time, this provides a possibility for rapid replacement. To ensure the optimum system structure, taking into account the ratio of price for unit density of covered area [2] the network consists of 9 single local drones, each covering about $20 \mathrm{~km}^{2}$ of the urban area of a total of $180 \mathrm{~km}^{2}$.

The system requires the development and integration of four key components:

- multi-platform network system including unmanned aerial platforms 9 single local unmanned platforms (UAVs Neighborhood) and one central platform (City UAV));

- sensor subsystem of small size, weight and power consumption suitable for the installation on air platforms that allows the complete monitoring of the urban environment and low-flying small moving objects;

- algorithms and software for the implementation of detection, classification and tracking of small UAV located within the area of responsibility of the system;

- center for management, maintenance and processing of the information.

The Central aircraft (City UAV) detects small flying moving objects and provides a complete surveillance of the area of responsibility, which is $180 \mathrm{~km}^{2}$ [2]. The radar detects UAV and transmits to the Centre for management and information processing its characteristics and affiliations. It establishes whether there are open applications and UAV flight plans in the management of air traffic, and then if everything is according to the rules, it ceases to be of interest to the network aerial system. However, if the flying object has no transponder and does not meet the requirements, the City UAV immediately directs the closest local drone (UAVs Neighborhood), which collects the additional required information $\left(20 \mathrm{~km}^{2}\right)$ that characterizes it (dimensions, type, destination, speed, altitude) and transmits them to the command center for making necessary decisions (Fig. 1). 


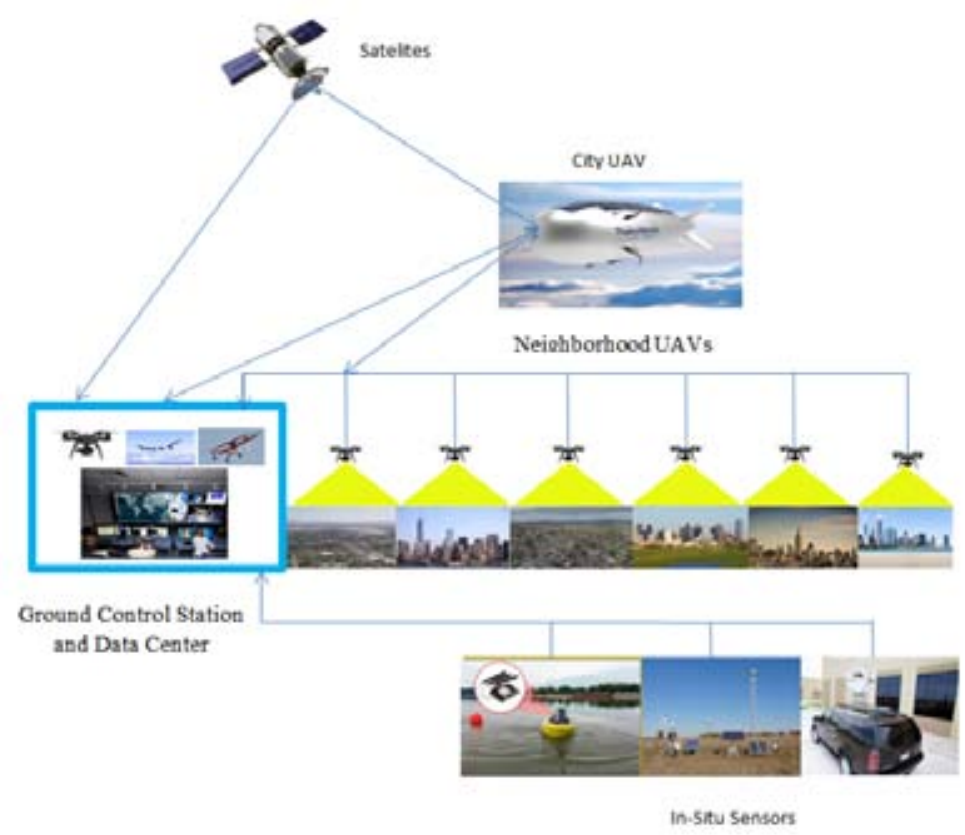

Fig. 1

The information flow could be described by the following data types: Correction data - correction signal for the highest rate positioning accuracy (NTRIP data); information data - the information data from the Neighborhood UAVs and the City UAV on the Fig. 1; sense and avoid data - data for the position, altitude, heading and speed transmitted to all of the Neighborhood UAVs and the Data and control center (Ground Control Station and Data Center).

The Neighborhood UAVs will be able to communicate to each other via encrypted and secured direct MAV radio link, which will provide at least 2-5 km of reliable radio connection in the urban area. The entire information is then transmitted via direct UAV radio link to the City UAV. Due to the long distance between the communicating Neighborhood UAVs, a cell tower from a mobile operator should be used. Using the data from the GCS for the positioning (NTRIP), the correction signal is transmitted to each of the Neighborhood UAVs and processed. As a result each video frame recorded and picture taken on the UAVs will be geotagged with the highest positioning accuracy and precision. The result is fast and accurate locating of any intruder in the sky. Additionally, the highest accuracy of positioning would deliver accurate and safe control of the Neighborhood UAVs in the urban area, lower power consumption and longer flight endurance compared to standard GPS positioning. 
The use of cell towers of mobile operators to transmit the data will increase the range of the transmission within the coverage of the mobile operator network, which in urban areas would be practically unlimited. Using this method for data transmission will provide fast, accurate and full integration, and will reduce the weight of the additional equipment, used on the City UAVs and Neighborhood UAVs that will consist of a single SIM modem, which will make the following activities possible:

- Transmission of the data from the sensors - video frames, pictures, LIDAR images; RGB/NDVI/NIR images and etc.

- Accuracy correction, positioning and control - NTRIP positioning with $2.5 \mathrm{~cm}$ absolute accuracy, geotagging of images and frames.

- Transmission of the Sense \& Avoid Data - this data will provide full information for the position of all UAVs used by the Dragnet Network, will increase the safety and will optimize the control of each particular UAV.

The possibilities for high grade accuracy positioning of UAVs are quite limited. The reason for that is the cost for developing pin-point accuracy service and the limitation of the maximum take-off weight (TOW) of the UAVs.

In present days (Q3 2017) there are not many known solutions, provided specially for UAVs. Some of the most spread and commonly used solutions are:

- Piksi RTK (provided by Swift Nav) - Swift Nav has developed some of the cheapest RTK solution for UAVs. Their electronic modules are based on the usage of RTK direct radio link with single base station. That solution provides the flexibility for the user to establish the RTK base station practically anywhere, within the direct line of sight, providing high grade accuracy and at the same time having the stand-alone integrity and autonomy for the positioning.

- Here+ RTK (provided by Hex Aero) [3] - Here+ RTK solution was specially developed for Pixhawk autopilot, which integrates open source hardware and software. It is also based on the single RTK base station and direct radio link. The main advantage of this solution is the usage of open source software, which makes it easily configurable for multiple autopilots and flight controllers, available on the market and its low price, compared to the quality.

- DJI D-RTK solution [4] - the solution for RTK from DJI is quite the same as the ones listed above. The main difference between the solutions, provided by Here+ and Piksi from one side and the solution from DJI on the other side is the fully integrated firmware and extremely friendly user interface for the setup and configuration of DJI products, which makes them very reliable and easy to use and they are very well known among the hobbyist and professionals worldwide.

These are just a few of the examples for high grade accuracy solutions for UAVs available in present days worldwide. The disadvantages of all of them however are quite the same and are present to all those products. Those disadvantages are the very small area of the coverage of the signal (up to $10 \mathrm{~km}$ ), low reliability (because of the radio link) and they are not suitable for urbanized 
areas and low-altitude applications on distances over $2 \div 3 \mathrm{~km}$ away from the base station.

Neighborhood UAVs can be multicopter platforms with electric propulsion - $\mathrm{MCP}_{\mathrm{ep}}$. Their flying and technical characteristics meet the requirements in the best way.

The high flying performances of this type of aircraft are due to the use of brushless electric motors with high specific power and efficiency. They are powered by lithium-polymer and other batteries with high specific energy and high energy density. Their control is precise, through lightweight, high speed controllers. Nowadays on the market there are $\mathrm{MCP}_{\text {ep }}$ with lifting characteristics, maneuverability, controllability, automation and robotics capabilities that are unthinkable in fixed-wing aircraft. The development of this type of aircraft has wide perspective. According to the latest data, in the small class UAV, consumer preferences are: $94 \%$ for multicopters, versus $6 \%$ for airplanes.

The $\mathrm{MCP}_{\text {ep }}$ require high thrust-to-weight ratio. When hovering and maneuvering in calm air they need a thrust that exceeds $1.2 \div 1.4$ times the total weight of the vehicle. In dynamic air environment the thrust-to-weight ratio reaches $1.8 \div 2.0$. To achieve these parameters, $\mathrm{MCP}_{\mathrm{ep}}$ must carry batteries of high capacity and weight on board.

The main problem with the use of $\mathrm{MCP}_{\mathrm{ep}}$ is the limited flight duration which is due to the high weight of the batteries. Currently electric propulsion of $\mathrm{MCP}_{\text {ep }}$ mainly uses lithium-polymer batteries. Their characteristics: specific energy $\mathrm{C}_{\mathrm{p}} \mathrm{E}_{\mathrm{c}}(\mathrm{Wh} / \mathrm{kg})$, energy density $\mathrm{C}_{\mathrm{p}} \mathrm{P}_{\mathrm{w}}(\mathrm{W} / \mathrm{kg})$, number of charge - discharge cycles, existence of "memory effect", etc. are superior to competing batteries: lead acid, nickel cadmium (NiCd), nickel metal hydride ( $\mathrm{Ni}-\mathrm{Mh})$, sodium chloride ( $\mathrm{NaCl})$.

From a study of the commercially available batteries, it was found that the $\mathrm{C}_{\mathrm{p}} \mathrm{E}_{\mathrm{c}}$ of lithium-polymer batteries did not exceed $300 \mathrm{Wh} / \mathrm{kg}$. Their theoretical maximum is $400 \mathrm{Wh} / \mathrm{kg}$. The next generations in the development of lithium batteries are lithium-sulphide and lithium-air batteries. It is expected their $\mathrm{C}_{\mathrm{p}} \mathrm{E}_{\mathrm{c}}$ to reach (600-1000) Wh/kg. Now Li-S batteries with $C_{p} E_{c}-380 \mathrm{Wh} / \mathrm{kg}$ are available on the market. However, they quickly lose their capacity and still have a very limited number of charge-discharge cycles. This makes it difficult to use them for the propulsion of $\mathrm{MCP}_{\mathrm{ep}}$.

The use of modern composites and other materials with high strength characteristics and low relative weight, coupled with the realization of effective constructive solutions allows the empty weight of the $\mathrm{MCP}_{\text {ep }}$ (with engines and propellers, without batteries and payload) to be reduced to $30 \%$, and the payload to reach $20 \%$ of the total weight of the vehicle.

The time for hovering of the multicopter will be: 
(1)

$$
t_{h}=\frac{E_{h}}{P_{h}}=\frac{\bar{E} m_{b}}{P_{h} \frac{m_{h}}{m_{h}} \frac{g}{g}}=\frac{\bar{E} \bar{m}_{b} \bar{F}_{h}}{g} \quad[h]
$$

where: $m_{h}[\mathrm{~kg}]$ - the mass of the multicopter in hovering; $\mathrm{g}\left[\mathrm{m} / \mathrm{s}^{2}\right]-$ ground acceleration; $F_{h}=m_{h} g[\mathrm{~N}]$ - needed thrust for hovering; $U_{b}[\mathrm{~V}]$ - average voltage for hovering; $A_{h}[\mathrm{~A}]$ - needed current for hovering; $P_{h}=U_{b} I_{h}[\mathrm{~W}]$ - needed power for hovering; $E_{h}=P_{h} t_{h}[\mathrm{kWh}]$ - needed energy for hovering; $\bar{E}=E / m_{b}$ [Wh $/ \mathrm{kg}]$ - specific energy of the batteries; $\bar{m}_{b}=m_{b} / m_{h}$ - specific mass of batteries; $F_{h}=F_{h} / P_{h}=m_{h} g / P_{h}[\mathrm{~N} / \mathrm{W}]-$ specific thrust for hovering;

If we take:

$m_{p}=5[\mathrm{~kg}]$ mass of the payload,

$\bar{m}_{p}=m_{p} / m_{h}=0,2-$ specific mass of the payload

$\bar{E}=300[\mathrm{Wh} / \mathrm{kg}]-$ specific energy of the batteries; $t_{h}=1 \mathrm{~h}$.

Then: $m_{h}=5 / 0,2=25[\mathrm{~kg}]$ - the mass of the multicopter in hovering,

$$
\begin{aligned}
\bar{m}_{b} & =t_{h} / \bar{E} \bar{F}_{h} g=1 \cdot 9,81 / 300 \cdot 0,11=0,3[\mathrm{~kg}], \\
m_{b} & =\bar{m}_{b} m_{h}=0,3.25=7,5[\mathrm{~kg}] .
\end{aligned}
$$

In our opinion, a solution of the above problems is the propulsion of $\mathrm{MCP}_{\mathrm{ep}}$ by an on-board hybrid power plant (OBHPP). It should include: an internal combustion engine (ICE), an electric power generator, a controller for its control and a buffer battery to provide emergency landing or, if necessary, a low noise and vibration flight.

The OBHPP can provide a thrust-to-weight ratio exceeding 2.0 times the total weight of the $\mathrm{MCP}_{\mathrm{ep}}$, long time of hovering in one position in a turbulent air environment, high horizontal speed and precise control when changing location, powering all consumers at different payloads and flight duration of more than 2 hours.

There is information about the following hybrid propulsion versions of $\mathrm{MCP}_{\mathrm{ep}}$ :

- by using fuel cells, fed by hydrogen from a tank that the multicopter carries on board; 
- a combined drive by co-located ICE and an electric motor with propellers, mounted at the end of each of the multicopter arms, the ICE generates the main thrust, control is done with the electric motors;

- an ICE with a fan that generates the main thrust is located centrally in the $\mathrm{MCP}_{\text {ep }}$ fuselage, the stabilization and flight control are realized with electric motors located on the arms.

We believe that ICE is most suitable for OBHPP. Using liquid hydrocarbon fuels of high calorific value, they outperform all existing batteries and fuel cells. For $\mathrm{MCP}_{\mathrm{ep}}$, depending on their size, the required power is in the range $1.0 \div 10.0 \mathrm{~kW}$. For this power range, the efficiency of existing internal combustion engines is $5 \div 28 \%$. The highest value is for four-stroke engines - with reciprocating piston movement and rotary ones (Wankel). For those with spark ignition (operating on the Otto cycle), the efficiency is up to $25 \%$ and for with compression ignition (Diesel) - up to $28 \%$. For two-stroke engines the efficiency is $5 \div 10 \%$ lower. However, they are preferable for use in a hybrid drive of $\mathrm{MCP}_{\mathrm{ep}}$. Their advantages are: a simple design, low weight and price, high specific power (up to 1.8 times greater than that of a four-stroke ICE with the same displacement), high reliability and repairability [27-30].

Characteristics of currently available two-stroke gasoline ICE for use mainly in fixed-wing UAV that can be used for OBHPP are presented in Table 1.

When an OBHPP is powered by a gasoline two-stroke engine with $20 \%$ efficiency, the specific energy of the hybrid power plant would be more than $2000 \mathrm{Wh} / \mathrm{kg}$.

In the engines listed in Table 1, the latest achievements in the design, materials, organization and control of the combustion process in two-stroke ICE have not been implemented. This allows the creation of engines with up to $25 \%$ efficiency improvement. An OBHPP, powered by such an engine, will have $\mathrm{C}_{p} \mathrm{E}_{\mathrm{c}}$ above $3000 \mathrm{Wh} / \mathrm{kg}$.

It should be noted that there is still no suitable generator with features that allow it to be optimally built in OBHPP. So far brushless generators with permanent magnets are available, but with much lower power and higher specific gravity than necessary. This requires the implementation of innovative technical solutions for electric generators of OBHPP. They consist of the following: the use of new generation permanent magnet, ceramic bearings, structural material, a common housing with Internal Combustion Engines and reduction gear, the opportunity to work in a starter and generator regime, a unique original design, high efficiency and other performance data. 
Table 1

\begin{tabular}{|c|c|c|c|c|}
\hline Engine type & $\begin{array}{c}\text { Desert Air } \\
\text { DA - } 150\end{array}$ & $\begin{array}{c}\text { Evolution } \\
\text { Engines } \\
116 \text { Gx2 }\end{array}$ & $\begin{array}{l}\text { Graupner } \\
\text { G } 58\end{array}$ & $\begin{array}{c}\text { Modellmotoren } \\
\text { 3W-157XIB2 }\end{array}$ \\
\hline $\begin{array}{c}\text { Displacement - } \\
\mathrm{cm}^{3} / \text { no. of } \\
\text { cylinders }\end{array}$ & $150 / 2$ & $116 / 2$ & $58 / 1$ & $157 / 2$ \\
\hline $\begin{array}{c}\text { Produced power } \\
-\mathrm{kW} / \mathrm{rpm}\end{array}$ & $12.3 / 6000$ & $6.3 / 6950$ & $6.3 / 6950$ & $14.3 / 8500$ \\
\hline Weight - kg & 3.61 & 1.82 & 1.63 & 4.14 \\
\hline $\begin{array}{c}\text { Specific } \\
\text { power }-\mathrm{kW} / \mathrm{kg}\end{array}$ & 3.40 & 3.48 & 3.88 & 3.48 \\
\hline Efficiency - \% & 18 & 20 & 21 & 14 \\
\hline
\end{tabular}

The innovative $\mathrm{UAV}_{\mathrm{mt}}$ scheme for generating electricity on board requires the creation of entirely new automated system for the production, management, storage and distribution of electric power on board, based on new methods of design and use of new technologies and the most modern existing components, processors and semiconductor components.

The motor-generator group will be zero-reactive point, which is extremely important for the stability and manageability of multicopter systems. The moment of an OBHPP jet engine with AWD system electric generator, will be fully compensated.

When approximate estimates for the hybrid propulsion $\mathrm{UAV}_{\mathrm{mt}}$ are made, analogous to the power take-off with AMO with electric batteries, it is established that, with take-off mass of $50 \mathrm{~kg}$, payload $-5 \mathrm{~kg}$ and thrust to weight ratio of 1.8, the flight duration in troubled air is between 2 and 3 hours, which is many times greater than the one only with batteries.

We believe that an OBHPP will be of interest to the European and world market and it can be realized in $\mathrm{UAV}_{\mathrm{mt}}$ and other unmanned aerial vehicles. It can find application in the terrestrial surface and remotely operated equipment with civilian and military use as well as for emergency power supply in manned light aircraft, fixed telecommunication facilities, observation posts, etc., everywhere low weight and dimensions are required. 
If this hybrid power plant is mounted on a fixed-wing UAV with the same total weight of $50 \mathrm{~kg}$, speed $-150 \mathrm{~km} / \mathrm{h}$ and quality - 10, the endurance of this aircraft will be significantly greater (about 7 hours) which can be explained by the much lower power needed due to the higher aerodynamic quality. Taking this into account, it is suggested to use a fixed-wing UAV with a hybrid on-board power plant for the central control system.

To a large extent, the characteristics of the selected types of platforms and the safety of the system is determined by the weight and dimensions of the sensor subsystem used for the monitoring of the area of responsibility. Existing sensors for detecting, classifying and tracking urban UAVs are cameras and systems operating in the visible and infrared spectrums, radars operating on different physical principles to explore systems of type a-alien, "sonar" systems, etc.

To detect small targets in urban conditions, portable radars are used to survey the monitored area. Continuous Wave (CW) radars are used for this purpose, which involve Frequency Modulated Continues Wave (FMCW) radars and Doppler radars. In the first group, periodic variations in the frequency are used to determine the range to the target, while the second uses the Doppler Effect. Modern miniature radars combine both modes of operation. Practically, systems usually work in Doppler mode until target is detected, and once the target is detected, the FMCW mode is activated to determine distance-to-target information. In this case, a relatively low level of false alarms is maintained by reacting only to the targets with some radial velocity relative to the radar. Furthermore, the overall reaction time is decreased by the use of Doppler mode since a target's presence and velocity can be acquired from a single sample window, whereas FMCW must use multiple sample windows to determine the velocity based on the differentiated ranges [12-14].

Since most aircraft, while on the move contain rotating components moving in a periodic sequence, there is a unique Doppler signature for most devices. Prior knowledge of this "signature" can be used to determine in real time the presence of a known target within the currently depicted scene. There are numerous ways to define the signature of targets, but most commonly the identification methods include the use of a parametric target model [12-14].

This approach is appropriate for certain groups of aircraft because of the smaller number of types and variants of the group of vehicles. However, for a certain group of miniature UAVs (with a mass $<25 \mathrm{~kg}$ ), the number of possible variants is considerably higher. From a practical point of view, this implies that nonparametric patterns are preferred when manual generation of a parametric model for each UAV option is not applicable [12-14, 17].

In Table 2 are given parameters of on-board radars used in UAV [14-16]. 
Table 2

\begin{tabular}{|c|c|c|c|}
\hline Company & Transponder & Size/Weight & Input Power \\
\hline $\begin{array}{c}\text { uAvionix } \\
\text { Corporation }\end{array}$ & Ping200Si ADS-B & $91 \times 57 \times 19 \mathrm{~mm} / 80 \mathrm{~g}$ & $11-33$ VDC, 2W \\
\hline Sagetech & XPC-TR Mode C & $89 \times 46 \times 18 \mathrm{~mm} / 100 \mathrm{~g}$ & $10-32$ VDC \\
\hline Sagetech & XPS-TR Mode S with ADS-B & $89 \times 46 \times 18 \mathrm{~mm} / 100 \mathrm{~g}$ & $10-32$ VDC \\
\hline Sagetech & $\begin{array}{c}\text { XPG-TR Mode S Transponder } \\
\text { with ADS-B Out and GPS }\end{array}$ & $102 \times 47 \times 26 \mathrm{~mm} / 147 \mathrm{~g}$ & $10-32$ VDC \\
\hline
\end{tabular}

A great deal of attention is paid to the development and use of on-board radars for UAV for issues regarding the identification of detected in open air and on the ground targets. At present, a lot of companies are producing high-tech and reliable S-mode transponders. They provide the information needed to identify UAVs by the air traffic management and the UAV Control and Management Center.

In Table 3 are given the parameters of transponders used in UAV [18, 19]. After the detection and identification of an object, surveillance systems further recognize it, and then, if necessary, follow the object's trajectory.

A major component of the surveillance systems are surveillance cameras in the visible and infrared spectrum. They are located on stabilized platforms with the ability to direct the cameras to three coordinates in space.

Table 3

\begin{tabular}{|c|c|c|c|c|c|}
\hline Company & Radar & $\begin{array}{c}\text { Transmitted } \\
\text { frequency/ } \\
\text { Transmitted } \\
\text { Power }\end{array}$ & $\begin{array}{c}\text { Range } \\
\text { /Field of } \\
\text { view }\end{array}$ & Size/Weight & $\begin{array}{l}\text { Input } \\
\text { Power }\end{array}$ \\
\hline & $\begin{array}{l}\text { FMCW/ } \\
\text { Doppler }\end{array}$ & $\begin{array}{c}10.5 \mathrm{GHz} / \\
10 \mathrm{~mW}\end{array}$ & & $155 \times 100 \times 90 \mathrm{~mm} / 230 \mathrm{~g}$ & $\begin{array}{c}10-42 \mathrm{~V} \\
\text { DC }\end{array}$ \\
\hline Echodyne & $\begin{array}{c}\text { Metamaterials } \\
\text { Electronically } \\
\text { Scanning } \\
\text { Array }\end{array}$ & & $3 \mathrm{~km} / 120 \times 80^{\circ}$ & $180 \times 100 \times 10 \mathrm{~mm} / 750 \mathrm{~g}$ & \\
\hline $\begin{array}{l}\text { Unmanned } \\
\text { Systems } \\
\text { Research } \\
\text { Institute }\end{array}$ & $\begin{array}{l}\text { Phased-array } \\
\text { radar }\end{array}$ & & $100 \mathrm{~m}$ & $350 \mathrm{~g}$ & \\
\hline InSAR & $\begin{array}{l}\text { NanoSAR/ } \\
\text { Synthetic } \\
\text { Aperture } \\
\text { Radar }\end{array}$ & $\mathrm{X}$ band & $1 \mathrm{~km} / 1 \mathrm{~m}$ & $158 \times 190 \times 114 \mathrm{~mm} / 900 \mathrm{~g}$ & \\
\hline $\begin{array}{l}\text { Brigham } \\
\text { Young } \\
\text { University }\end{array}$ & MicroSAR & $\begin{array}{c}\mathrm{X} \text { band } \\
(9.75 \mathrm{GHz})\end{array}$ & & $120 \times 800 \times 400 \mathrm{~mm} / 2.8 \mathrm{~kg}$ & $\begin{array}{c}12-18 \mathrm{~V} \\
\mathrm{DC}\end{array}$ \\
\hline
\end{tabular}


Surveillance cameras supporting Ultra High Definition TV $(3840 \times 2160)$ $4 \mathrm{~K}$ standard with maximum resolution $8 \mathrm{M}$ pixels and surveillance cameras supporting HDTV standard $(1920 \times 1080)$ with maximum resolution $2 \mathrm{M}$ pixels are used in the visible area.

For the first type of cameras, when the simultaneous observation of the entire area of $20 \mathrm{~km}^{2}$ is performed, the size of 1 pixel in the observed scene is $2.4 \mathrm{~m}^{2}$ or $1.6 \times 1.6 \mathrm{~m}$. In order to recognize objects measuring $0.5 \times 0.5 \mathrm{~m}$ in the observed scene, a resolution of at least $8 \times 8$ or $10 \times 10$ pixels is necessary, i.e. the pixel size should be $7 \times 7 \mathrm{~cm}$ or $5 \times 5 \mathrm{~cm}$. This resolution can be achieved by reducing the viewed area and using variable focus lenses (zoom lenses).

When using a lens with a fixed focal length, it may cover an instantly observed area of $20736 \mathrm{~m}^{2}(144 \times 144 \mathrm{~m})$ with a resolution of $5 \times 5 \mathrm{~cm}$.

When using a $\times 10$ zoom lens, a viewing area of $0.2 \mathrm{~km}^{2}(455 \times 455 \mathrm{~m})$ can be observed at any given time and further focused on with a zoom lens for a $5 \times 5 \mathrm{~cm}$ resolution for the purpose of object recognition.

For the second type of cameras (with a lower price) when using a $\times 10$ zoom lens and HDTV camera can be captured an area of $0.05 \mathrm{~km}^{2}(227 \times 227 \mathrm{~m})$ with a $15 \times 15 \mathrm{~cm}$ resolution and further focused with the help of a zoom lens for a $5 \times 5 \mathrm{~cm}$ resolution for the purpose of object recognition.

In the infrared or thermal spectra, the surveillance cameras support a significantly lower resolution, with good samples reaching a resolution of $640 \times 480$ pixels. They are used for observation in bad weather or other conditions and at night. They are commonly used with surveillance cameras in the visible area, with the two images being able to be mixed. Analyzes are presented in Table 4.

In the recent years due to the strong demand for drone detection, identification and tracking systems, a new major technological approach has been established - the acoustic method. A few companies are offering detection, identification and tracking systems involving the acoustic approach. Such a system is SafeSky Drone Detection and Neutralization System [20] by Advanced Protection Systems. Their acoustic array detects drones from up to several hundred meters. Furthermore, this system is a combination of proprietary X-band radar, acoustic array, camera for visual detection, and RF sensors. The most contemporary and cutting-edge technological method for acoustic drone control is a further development of the acoustic array detection system leading to the acoustic camera drone detection method. Companies that have large experience in acoustic cameras intended for other applications are trying to adapt their products and knowledge and create drone control acoustic cameras. Preliminary testing is carried out by the Swiss company Distran [21]. The company has been developing ultrasonic acoustic cameras like Ultra $\mathrm{M}$ used for ultrasonic examination and detection of mechanical faults in industrial equipment. 
Table 4

\begin{tabular}{|c|c|c|c|c|c|}
\hline $\begin{array}{l}\text { Spectral } \\
\text { region }\end{array}$ & $\begin{array}{l}\text { Standard / } \\
\text { sensor pixels }\end{array}$ & $\begin{array}{l}\text { Lens } \\
\text { type }\end{array}$ & Observed area & $\begin{array}{l}\text { Spatial } \\
\text { resolution }\end{array}$ & $\begin{array}{l}\text { Maximum } \\
\text { spatial } \\
\text { resolution }\end{array}$ \\
\hline \multirow{5}{*}{$\begin{array}{l}\text { Visible } \\
\text { (Vis) }\end{array}$} & \multirow{3}{*}{$\begin{array}{c}\text { UHDTV } \\
3840 \times 2160\end{array}$} & \multirow{2}{*}{$\begin{array}{l}\text { Fixed } \\
\text { focus }\end{array}$} & $20000 \mathrm{\kappa m}^{2}$ & $\begin{array}{c}2.4 \mathrm{~m}^{2} \\
(1.6 \times 1.6 \mathrm{~m})\end{array}$ & \\
\hline & & & $\begin{array}{c}20736 \mathrm{~m}^{2} \\
(144 \times 144 \mathrm{~m})\end{array}$ & & $5 \times 5 \mathrm{~cm}$ \\
\hline & & $\begin{array}{l}\text { Zoom } \\
\text { lens }\end{array}$ & $\begin{array}{c}0.2 \mathrm{~km}^{2} \\
(455 \times 455 \mathrm{~m})\end{array}$ & & $5 \times 5 \mathrm{~cm}$ \\
\hline & \multirow[b]{2}{*}{$1920 \times 1080$} & $\begin{array}{l}\text { Fixed } \\
\text { focus }\end{array}$ & $\begin{array}{c}0.05 \mathrm{~km}^{2} \\
(227 \times 227 \mathrm{~m})\end{array}$ & $15 \times 15 \mathrm{~cm}$ & \\
\hline & & $\begin{array}{l}\text { Zoom } \\
\text { lens }\end{array}$ & $\begin{array}{c}0.05 \mathrm{~km}^{2} \\
(227 \times 227 \mathrm{~m})\end{array}$ & & $5 \times 5 \mathrm{~cm}$ \\
\hline $\begin{array}{l}\text { Infrared } \\
\text { (IR) }\end{array}$ & $\begin{array}{c}\text { TV } \\
640 \times 480\end{array}$ & $\begin{array}{l}\text { Fixed } \\
\text { focus }\end{array}$ & $\begin{array}{c}0.05 \mathrm{~km}^{2} \\
(227 \times 227 \mathrm{~m})\end{array}$ & $35 \times 45 \mathrm{~cm}$ & \\
\hline
\end{tabular}

Other manufacturers of acoustic cameras, though not yet specialized in drone detection, are Acoustic Camera [22], Cae-Systems in Germany [23], Microflown [24], NLA Acoustics [25], Norsonic [26] etc.

The advantage of acoustic cameras over other acoustic methods for detection is the generation in real-time of acoustic color visualization of the observed volume and visual signaling of the operator about the position and other characteristics of the detected and tracked drone/drones.

In the Center for the operation, management and processing of received data and coordinates of the UAV flights in the airspace of intelligent city are received, analyzed and structured. The large volume of information received by them is networked with other similar centers, with cloud structures and with users of processed information. It carries out the maintenance of the UAV. After landing they are checked, information stored onboard is downloaded, reprogrammed and again depart on schedule.

In the Center for data processing is done the recognition of small drones resulting from images from cameras mounted on anchored platforms. Development of software for processing is performed on 3 main stages:

- the first stage involves creating algorithms for detection of small drones written in high level language: MatLab, IDL, TensorFlow and others;

- after setting up and tuning the algorithms proceed to their application in workstations for the collection of information in real conditions. There can be used 
C, C++ CUDA or another language which allows speeding up the process of treatment;

- in the third stage-adapted algorithms tuned to specialized hardware mounted on board of the Central UAV using the DSP, FPGA, GPU or another approach allowing rapid real-time processing of the information received are implemented.

All these elements provide the necessary hardware, software, qualified staff and resources for long term and sustainable operation of the system.

\section{Conclusions}

The proposed concept and functional network scheme for an unmanned aerial system is the solution of the paradigm to detect, identify and track low-flying aircraft in urban terrain area characterized by tall buildings, moving people and vehicles, as well as in the presence of other sources of electromagnetic, thermal, and other emissions.

Conducted analysis and studies show that the development and use of hybrid power on-board unit will solve the issue of the flight endurance of unmanned platforms included in the composition of a network an unmanned aerial system and will increase the permissible weight for the sensor payloads, enabling the monitoring of the overall urban environment and low flying small moving objects.

Using the SIM modem on each UAV will provide the main advantages amongst any other technology for transmitting data and in flight communication: full integration; small dimensions and weight with practically unlimited range; high-end redundancy; full control of UAV; multi-data transmission.

Application of Phased Array Radars on the basis of new technologies and new signals and methods for their processing on board of UAV will increase their capabilities in urban areas.

The technology described, as a final conclusion will be the next century technology which will make the difference and will bring high-end accuracy together with all of the needed data during flight of any of the UAV in particular area, which will be the focus of all future regulations, regarding the usage of UAVs in urban areas.

\section{Acknowledgements}

I. The study was performed with the use of the:

1. Set up under the project BG161PO003-1.2.04-0053 "Information complex for aerospace environmental monitoring" (IKAMOS), financed by the operational program "Development of the competitiveness of the Bulgarian economy" 2007-2013, co-financed by the European Regional Development Fund and from the national budget of the Republic of Bulgaria. 
2. Project "Strengthening and Expansion of the Aerospace Technology Transfer Office in the Field of Protection of Citizens' Health in Disasters" BG161PO003-1.2.02 under the Operational Program "Development of the Competitiveness of the Bulgarian Economy" 2007-2013.

II. The authors gratefully acknowledge the support of K. C. Wong Education Foundation.

\section{References}

1. World's population increasingly urban with more than half living in urban areas, 10 July 2014, N. Y. http://www.un.org/en/development/desa/news/ population/worldurbanization-prospects-2014.html (accessed on 10 Dec. 2017)

2. Alberding GMbH Solutions. https://www.alberding.eu/en/ntripcaster.html\#pic8

3. Hex Aero. http://www.hex.aero/ (last day accessed 10 December 2017).

4. DJI D-RTK. https://www.dji.com/d-rtk/info (last day accessed 10 December 2017).

5. Dragnet overview. https://www.virginiabids.us/virginia-bids/bids-

ADP14758857890000992.htm (last day accessed 10 December 2017).

6. Aero Vision. www.aero-vision.net (last day accessed 10 December 2017).

7. CNH Industrial. http://www.cnhindustrial.com/en-us/Pages/homepage.aspx

8. Interagri Bulgaria JSC. http://www.interagri.bg/ (last day accessed 10 December 2017).

9. Precision Hawk. http://www.precisionhawk.com/latas (accessed on 10 December 2017)

10. Trimble Positioning Services. http://www.trimble.com/positioning-services/pdf/ whitepaper_rtx_fast.pdf (last day accessed 10 December 2017).

11.18 ${ }^{\text {th }}$ International Technical Meeting report. http://www.geopp.com/pdf/ion2005_fw.pdf

12. 3DR Robotics. https://3dr.com/ (last day accessed 10 December 2017).

13. Allistair Moses Matthew J. Rutherford, Kimon P. Valavanis, Radar-Based Detection and Identification for Miniature Air Vehicles, 2011 IEEE International Conference on Control Applications (CCA) Part of 2011 IEEE Multi-Conference on Systems and Control, Denver, CO, USA. September 28-30, 2011, 933-940.

14. Moses, A. M.J. Rutherford, and K.P. Valavanis, Radar-based detection and identification for miniature air vehicles, 2011 IEEE International Conference on Control Applications (CCA), Denver, CO, 2011, 933-940. DOI: 10.1109/CCA.2011.6044363 (last day accessed 10 December 2017).

15. Long, D., Compact, low-cost synthetic aperture radar, 30 December 2006, SPIE Newsroom. DOI: 10.1117/2.1200610.0456

16. Boyle, A. Echodyne gets $\$ 29 \mathrm{M}$ from NEA, Bill Gates and others to boost radar for drones, GeekWire - Space \& Science. https://www.geekwire.com/2017/echodynegets-29m-boost-nea-bill-gates-others-low-cost-radar/ (online on May 22, 2017).

17. Synthetic Aperture RADAR. http://www.barnardmicrosystems.com/UAV/features/ synthetic_aperture_radar.html (last day accessed 10 December 2017). 
18. Ji, Z., Hu, E., Zhang, Y. et al. Research on micro-Doppler feature of spatial target, J. Wireless Com. Network, 2017, 177. DOI: 10.1186/s13638-017-0963-7

19. ADS-B Transceivers, Receivers and Navigation Systems for Drones, http://www.unmannedsystemstechnology.com/company/uavionix-corporation/

20. UAV Transponders \& Tracker Kits. http://www.unmannedsystemstechnology.com/ company/sagetech-corporation/ (last day accessed 10 December 2017).

21. Advanced Protection Systems. http://www.detectdrones.com/\#system (10 Dec. 2017).

22. Distran. https://www.distran.ch (last day accessed 10 December 2017).

23. Acoustic Camera. https://www.acoustic-camera.com/en.html (10 Dec. 2017).

24. CAE Systems. https://www.cae-systems.de/en/products.html (10 Dec. 2017).

25. Microflown Technologies. http://www.microflown.com (accessed on 10 Dec. 2017).

26. Noiseless Acoustics. http://www.nlacoustics.com (last day accessed 10 December 2017)

27. Acoustic Camera Nor848A. https://web2.norsonic.com/product/324/(10 Dec. 2017).

28. Ravi, A. and A.S Arena, Jr., UAV Power Plant Performance Evaluation, Department of Mechanical \& Aerospace Engineering Oklahoma State University, 49-th AIAA Aerospace Science Meeting including the New Horizons Forum and Aerospace Exposition, 4-7 January 2011, Orlando, Florida, 1-6.

29. Campbell, C., E. Dittman, J. Mac Rae, C. Ehringer, A. Stone, K. Lake, S. Haskin, and R.R. Mankbadi, Design of a Hybrid Electrical Propulsion System, Embry-Riddle Aeronautical University and the FCAAP, Daytona Beach, $52^{\text {nd }}$ AIAA/ASME/ASCE/AHS/ASC, Structures, Structural Dynamics and Materials Conference 4-7 April 2011, Denver, Colorado, 2-4.

30. Schomann, J., Hybrid-Electric Propulsion System for small Unmanned Aircraft, Technical University of Munich, Thessis, 15-26.

31. Richard, R. Glassock, Design, Modelling and Measurement of Hybrid Powerplant for Unmanned Aerial Vechicles, School of Electrical Engineering and Computer Science Queensland University of Technology, M.Sc. of Engineering, 9-17. 


\section{БЕЗПИЛОТНА СИСТЕМА ЗА НАБЛЮДЕНИЕ В ГРАДСКА СРЕДА}

П. Гецов, В. Бо, Д. Зафиров, Г. Сотиров, Ст. Начев, Р. Янев, П. Граматиков, В. Атанасов, Хр. Лукарски, Св. Забунов

\section{Резюме}

Предложена е концепция за мрежа от безпилотни въздушни системи за събиране на информация в градска среда. Различните възможности се оценяват с помощта на различни видове въздухоплавателни средства, сензори и системи за получаване на необходимата цел, инструментална информация в реално време за подпомагане на вземането на адекватни и обосновани управленски решения, които значително ще допринесат за подобряване на качеството на живот на населението. Системата може да се използва за откриване на летящи обекти, за наблюдение, управление и сигурност на градските кръстовища, метростанции, обществени и частни сгради и за определяне състоянието на атмосферата и водните зони. Тя ще осигури възможност за прогнозиране и управление на кризи, които могат да възникнат в контекста на критичната градска инфраструктура. 